\title{
STUDENTS' PERCEPTIONS AND THEIR DERIVED SATISFACTION OF URBAN FORESTS IN THE MOST INDUSTRIALISED REGION OF POLAND
}

Agnieszka Sobol, PhD (ORCID: 0000-0002-4363-8923) - Institute of Urban and Regional Development

Piotr Skubała, Prof. (ORCID: 0000-0002-9209-0167) - Faculty of Natural Sciences at the University of Silesia in Katowice

Correspondence address:

Institute of Urban and Regional Development

Cieszyńska 2, 30-015 Kraków, Poland

agnieszka.sobol14@gmail.com

ABSTRACT: In the face of growing urbanised areas, the presence of forests and their appropriate shaping is a key challenge for contemporary urban planning. The importance of forests is largely identified with natural, economic and social functions in non-urban areas; however, forests are of vital value in urbanised areas. This article explores young Polish urbanites' awareness of the role forests play, and submits diagnoses of the forests multidimensional benefits and their functions in Poland's urban areas. Moreover, the research is based on the premise that the management of urban forests must ultimately lead to the satisfying of social needs. Based on empirical research, the perceptions of the value of urban forests as assessed by young people (students) in the Śląskie Voivodeship are presented, leading to the authors' postulation that urban forests are underestimated resources. Furthermore, the study suggests that young Poles do not recognise the multi-beneficial aspects of urban forests; and the authors indicate feasible directions for local policy to achieve sustainable development. The final statements argue that in the face of serious threats to the functioning of Earth's ecosystem, a campaign for the presence of forests and green spaces in cities is necessary.

KEYWORDS: ecosystem services, local planning, Polish cities, urban forests 


\section{Introduction}

The ongoing demographic and urbanisation pressures threaten ecosystems worldwide as these processes drive a large-scale conversion of rural to urban landscapes (Seto et al., 2011). Foreseen effects have a huge impact on climate change on a global scale (European Environment Agency, 2012). These changes require a complex sustainable development policy as their impact is multidimensional: on societies, the environment and the economy.

Sustainability in cities can be supported by the concept of ecosystem services, where environmental aspects are integrated and more directly embedded into urban decision planning (Andersson et al., 2015). Ecosystem services are not simply an outcome of ecological systems but rather are coproduced by human beings and nature. The ecosystem services approach also looks for more nature-based methods to climate change aims. This means refocusing environmental management from technological to more socio-ecological principles (European Commission, 2015; Kabisch et al., 2016). Naturebased solutions can be characterised as "... the use of nature in tackling challenges such as climate change, food security, water resources, or disaster risk management, encompassing a wider definition of how to conserve and use biodiversity in a sustainable manner" (Balian et al., 2014:5). Urban environments are also associated with many health and mental problems. Orientation geared towards nature and human well-being requires community-based governance models. An important task is to raise community awareness of the benefits of ecosystem services.

In many parts of the world we can observe a focus on the 're-naturing' of urban areas. The greening of cities comprises many forms of urban green spaces: squares, parks, urban forests. The latter option can be a real response to climate change resilience and environmental sustainability. While urbanisation transforms more and more of the world's surface, urban forests can harbour quite high biological richness. The multi-functional positive impacts of the development of urban forests are especially beneficial in post-industrial cities (Lawrence et al., 2013). The mixture of different green and blue spaces within urban areas is recognised for their capacity, not only in terms of direct biodiversity support but also in generating social and economic benefits (Haase et al., 2014). Urban forests balance the ecology of the entire city. Urban forests are rich in ecosystem services and increase the resilience of cities; in other words: the ability to adapt and thrive in changing and challenging circumstances.

Forests introduce natural wilderness and increase biodiversity into urban space (Kowarik, Körner, 2005). Nevertheless, there is research suggesting that residents of cities prefer green spaces that have more direct 
signs of regular maintenance and care (Rupprecht, Byrne, 2014). This preference results in the shaping of urban green spaces limited mostly to so-called 'parkification' (Littke, 2015). Other studies demonstrate the discrepancy between green spaces developed by city administrations and those that adhere to citizens' preferences (Hartig et al. 2014; Luederitz et al., 2015). This suggests a need for more methods of local stakeholder engagement in the process of greening cities. The governance approach in urban forestry can provide a way to bridge the gaps between public authorities and citizens' knowledge, values and needs.

In view of rapid urbanisation, there is a growing interest to promote green spaces in cities. However, contrary to the wide variety of functions urban forests perform, poor attention is consistently paid to the management of green areas in cities or to so-called 'undeveloped greenery', most of which comprise forest areas. Many works have examined different contexts of urban forests, but the particular subject of city greening has not been thoroughly described in the literature.

The general aim of the research was to explore citizens' preferences, motivation and engagement in the usage and design of urban forests. In the study, we assess perceptions and valuations of urban forests by young people in Silesian cities in Poland, addressing different aspects of urban forests and incorporating multiple criteria that affect the sustainability of cities. A selection of ecological, social and economic questions examined in the research conducted among groups of students. The purpose of the research was to note whether there are statistically significant differences in the approach to urban forests between students of various fields of study. Our goal was also to observe whether there are significant statistical differences in the approach to urban forests between the male and female sex.

\section{The importance of urban forests}

Trees perform several ecosystem services for cities. The direct environmental benefits include air pollution removal, the cooling of air temperatures and carbon sequestration. The benefits that are of a social character account for better physical and mental well-being within a more aesthetically pleasing and green landscape. The economic benefits comprise, i.e. a higher level of attractiveness of the city and lower costs of health services. Wild urban ecosystems can provide various ecological, social and economic benefits, and these are always intertwined (Kowarik, 2011).

Forests affect air quality through the direct removal of different pollutants impacting citizens' health. In Poland, it is estimated that about 46.000 
premature deaths are attributable to air pollution each year (European Environment Agency, 2017). Air quality benefits of urban forests assume the form of different pollutants' uptake and deposition. There is considerable research on carbon sequestration and storage (CSS) thanks to trees in the urban landscape. Nowak and Crane (2002) estimated carbon sequestration averaging 22,8 Mt C Yr-1 and carbon storage of around $700 \mathrm{Mt}$ from urban parks and on streets in US cities. Based on studies mostly referencing American cities, annual carbon storage per tree range between 11 to $852 \mathrm{~kg}$. Net annual air quality benefits including ozone, nitrogen dioxide, sulphur dioxide and PM10 per tree range from 0,003 to $1,81 \mathrm{~kg}$ (Song et al., 2018). Other studies show that pollution removal by urban trees in the United States has been estimated at 651.000 tonnes per year (Nowak et al., 2014).

Green spaces combat the urban heat island (UHI) effect and reduce the impact of climate change. An increased provision of urban green spaces to ameliorate high temperature in cities was also identified (Gill et al., 2007; Bowler et al., 2010).

Nature is a great contributor to human well-being. A substantial amount of research has documented that the existence of urban green areas improves mental and physical health (Lee, Maheswaran, 2011; Carrus et al., 2015). A number of studies have illustrated the positive health effects of living in close proximity to green spaces. What is more, they reinforce cultural identities, supporting a sense of belonging and place (Keniger et al., 2013; Hartig et al., 2014). People's contact with nature in cities increases prosocial and community building behaviour (Zhang et al., 2014). Studies demonstrate that the direct use of urban green spaces supports nature-friendly policies (Bragg et al., 2013). The 'GREEN SURGE' project in five European cities studied the perceptions and values of residents (3800 respondents) in relation to urban greening. Despite the fact that, in general, citizens value forests and other green spaces, their perception vary among cities, suggesting that regional and cultural contexts matter in terms of their relationships with nature (Fisher et al., 2016).

Economic benefits of urban forestry in monetary values can be considered individually or for the whole community. There are different aesthetic and amenity effects of forests on the real estate market, which in turn affect property sales' prices. Birch and Wachter (2008) recognise the economic incentives of urban forests in terms of less costly ways of reducing problems connected with climate change, air and water pollution, flooding and heat island impacts. From an economic perspective, urban forests also contribute to tourism development.

The economic values of forests vary among cities depending on local conditions. Complex studies conducted in American and Canadian cities called 
attention to the economic benefits of urban forests. Based on the already cited studies by Song et al. (2018), the annual economic benefit per tree ranged between 7 to 165 USD. The studies also calculated the median annual costs and benefits per tree, including the following variables: biodiversity, aesthetic and amenity, shading, water regulation, carbon reduction, air quality, noise reduction, recreation and tourism, resource provision. The yearly complex benefit per tree was 44.34 USD and exceeded the costs, which amounted to 37.40 USD. Other studies by Nowak et al. (2014) show that air pollution removal by trees in the United States provided health benefits valued at 6.8 billion USD. Another research in 86 Canadian cities shows that the total amount of pollution removal was 16.500 tonnes, with human health value ranging between 38 to 292 million USD (Nowak et al., 2018). It is worth emphasising that these values are based on human health impacts. They would most likely increase if the impact on animals, crops, infrastructure, and buildings was considered.

The information given above point to the complex positive aspects of the development of urban green areas. Nevertheless, we should consider the existence of some negative aspects. In terms of the economic dimension and the real estate market, the installation of new green spaces or the restoration of existing green spaces may lead to increases in land prices and rent because of the increased attractiveness of the area. In turn, this can lead to a displacement process that is called the 'green paradox' (Wolch et al., 2014), eco-gentrification (Irvine et al., 2013; Haffner, 2015), ecological gentrification (Dooling, 2009), or environmental gentrification (Checker, 2011).

There were also identified so-called ecosystem disservices that can be defined as ecosystem functions rather negatively perceived by citizens. For example, they may relate to an increase in the numbers of insects, especially mosquitoes or an increase of allergic pollen in the air (Lyytimäki and Sipilä, 2009; von Döhren and Haase, 2015). Indirect costs of trees also include damage to buildings and pavements by tree roots or damage and disruption from falling branches (Vogt et al., 2015). It should be noted that ecosystem disservices only started to be recognised in the process of research being carried out.

Green areas have a generally positive effect on the holistic system of a city. Nevertheless, the power of an urban forest seems to be outstanding. In urban forests, nature is much less under the control of humans. It is more 'natural' with all its richness and density. The forest structure contributes to higher ecological resilience and variability than other green spaces in cities. Urban forests are therefore thought important for living sustainably alongside nature in cities. 


\section{Governance in the development of urban forests}

The concept of ecosystem services was originally developed to explain human-nature relationships (MA, 2005). However, after years of research, a need towards an interdisciplinary model of services of biodiversity regarding governance was identified. The advocates of such an approach indicate the positive impact of stakeholder participation on the decision-making process and better recognition of human-nature links (Chan et al., 2012; Turnhout et al., 2013). In line with this statement, the European Union has indicated that ecosystem service mapping can be used for: "explaining the relevance of ecosystem services to the public in their territory" (European Union, 2015).

The last years have witnessed a growing interest of both the residents and administration of different levels in ecological life. This nature-oriented way of living can be incorporated into health-promoting strategies and the building of healthier cities (Hartig et al., 2014). We can also observe that urban greening is conducted more often under the formula of governance. Citizens' involvement in green spaces management can be perceived as a part of a wider reorientation towards stakeholder participation in urban planning. Numerous initiatives of greening cities by the residents and other local actors have emerged in Europe and other parts of the world over the last decades (Jansson, Lindgren, 2012; Buijs et al., 2017). Nevertheless, the number of governance strategies in urban ecosystem services has been limited (Luederitz et al., 2015). Ostoic and Konijnendijk Van den Bosch (2015) checked 519 articles from 1988 to 2014 in four leading journals on urban green spaces, and they stated: "Studies related to active participation of citizens and partnerships in urban forestry have been missing" (p.129).

An optimal strategy for the development of urban forests requires the engagement of many different actors. Local administration needs to cooperate with the community to have an ally during the development and maintenance process. It should be asserted here that it is often a challenge for city administrations to allocate local budget funds for implementing and maintaining green space projects in cities. When society fails to understand the complex and long-term benefits of ecosystem services, it will inevitably exert pressure to direct the available financial resources towards other needs.

The indicated socio-ecological approach to environmental management includes more collaborative orientation of the development of green areas in cities. Incorporating different aspects and different partners in the process of development of urban green areas can increase their attractiveness and the recognition of the scope of their potential. In the governance approach, the management of green spaces is more reflective of citizens' ideas and builds 
stronger relationships with nature. Involving citizens can also lead to innovative approaches to land use planning. Nevertheless, stakeholder engagement in urban greening is a challenging task that requires complex coordination, good organisation and negotiations. Tensions may always arise.

In managing urban forests, there must be a public awareness strategy that leads to satisfying social needs (German-Chiari, Seeland, 2004). It is important to educate and engage residents in relation to urban ecosystem services. Arguably, at present, the decision-making process stands too much at a distance from local communities and their day-to-day practices. Governance towards designing and implementing urban forests requires more practical and more local context (McPhearson et al., 2015). The physical, social, cultural, economic and institutional diversity and a mixture of governance arrangements imply that there is no 'one-size fits all' strategy. For this reason, each community requires its own public participation approach in urban greening and consideration of what is best in its specific conditions.

The recognition of particular benefits of green areas becomes recognised through contact and direct practices. This illustrates how people value urban green areas and perceive them as a place. Place attachment is increased by the time spent there and visiting frequency and stakeholder participation in planning and maintenance of these places (Peters et al., 2010; Raymond et al., 2010; Chan et al., 2012; Turnhout et al., 2013). In addition, some studies show that a variety of local educational and practical activities hosted in urban green spaces increase engagement with these areas (Danforda et al., 2018). People can therefore feel the spirit of collective work, and along with experiences in cooperation, they can contribute to the development of urban green areas.

A range of linked benefits is underestimated both by societies and by city planners. This knowledge gap is a challenge that must be rejected in favour of fostering a socio-ecological agenda of environmental management in cities. It is important to examine the needs and ideas of citizens to incorporate forests into urban areas in an effort to build sustainable cities.

\section{Materials and methods}

\section{The general outlook on conditions of urban forests' development in Silesian cities (Poland)}

In Poland, there are three main acts of law concerning urban forests. These are The Environmental Protection Act (2001) and The Act on Spatial Planning and Management (2003), The Act on the Protection of Nature (2004). Taken together, they form integrative instruments which seek to 
establish the right proportion between built-up and biologically vital areas. These include the regulations regarding local plans that require a minimal size of the area covered by vegetation in relation to a plot size (ratio of biologically vital areas, RBVA). What is more, The Act of March 8th 1990 regarding local government in Poland, defines the development and maintenance of green spaces as public tasks which lie within the competences of local self-governments, who are tasked with commissioning documents that inform the local planning of green urban spaces and forests. The most important document of this kind is "The study of preconditions and directions for the spatial development of communities'. This study is a comprehensive, strategic plan that defines a city's spatial structure and its land use.

The Silesian (Śląskie) Voivodeship is located in the south of Poland. It is the most industrialised region in the country. Currently, the cities of the region are in the process of transformation, moving away from their ties to the mining industry. It is a long-term process, and full decarbonisation is estimated to last until the middle of this century. Silesia is also the most densely populated region in Poland and houses the largest conurbation of cities, numbering 41 cities and more than 3 million people.

Due to its industrial past, the environment in the region is very polluted. The biggest challenge is low-emission pollution from burning coal in domestic stoves and also transportation emissions. Greening the cities and urban forests development is a crucial element of the new 'Green Deal' policy in Silesia.

According to the statistics of the General Office of Geodesy and Cartography (GUGIK), the median value of the share of forests in Silesian cities in 2018 was $24.15 \%$. However, significant disproportions among individual cities should be noted, with the min-max values being $2.28 \%-85.32 \%$. Figure 1 shows the distribution of forest areas within the city limits of the Silesian Voivodeship in 2019 based on satellite data from OpenStreetMap (OSM). Moreover, the OSM data was analysed in terms of the indicator of inhabitants' accessibility to separate, coherent, larger green complexes within the administrative boundaries of the cities. The accessibility indicator value is expressed as the share of people living within a 15-minute walk to these complexes. The total number of such inhabitants for any given city is above $92 \%$ for all cities. This situation changes if a 5-minute walk time is adopted as the time to cover a distance of about $500 \mathrm{~m}$, as an adjustment for persons with reduced physical stamina, i.e. children, seniors or disabled people. In the case of this indicator, the median is $83.29 \%$, and the min-max values are $28.12 \%-99.97 \%$. Therefore, the above data indicate significant differences, both in terms of share and accessibility to urban forests in the cities of the Silesian Voivodeship. 


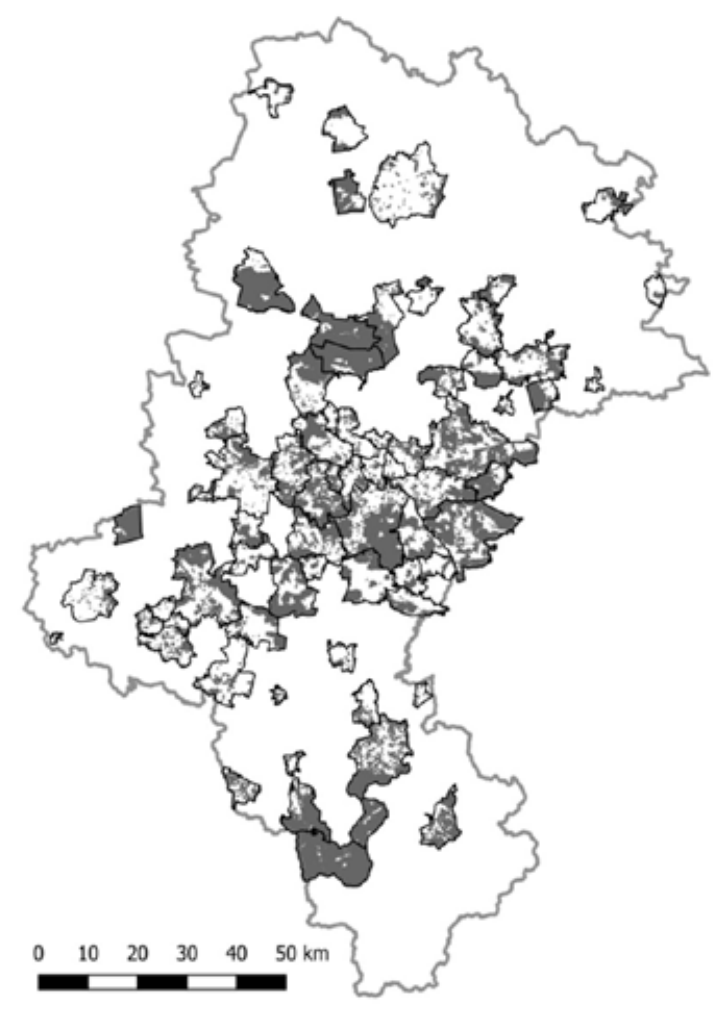

\section{Forests in the Śląskie Voivodeship}

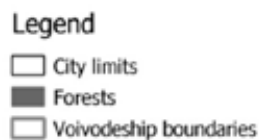

Source: OpenStreetMap [19.09.2019]

Figure 1. Urban forests in Silesian (Śląskie) Voivodeship

\section{Methods and statistics}

The study was based on an auditory questionnaire survey conducted in April-June 2019. The students of four different disciplines i.e., Spatial economy, Economics, Biology and Psychology were asked questions classified into ecological, economic and social issues. A total of 278 students were interviewed. In this study, we used a questionnaire to characterise the multidimensional context of urban forests.

In the first part, the questionnaire included 18 general knowledge questions related to ecological, social and economic aspects of urban forests. In ecological questions, we tried to get to know the respondents' knowledge about, among other things, the scale of deforestation on the Earth, how forest areas in the city affect air quality, biodiversity, hydrological situation, climatic conditions in cities, as well as the tendency to leave these areas without interference, including leaving deadwood. Regarding economic questions, we surveyed students' knowledge of the scale of the forest areas in the city 
economic value, whether they accept the urban policy allocating these areas for other purposes, and whether they would be willing to incur higher costs if they had a choice of real estate near forest areas. Regarding questions from the social category, we included questions testing respondents' knowledge (the impact of forest areas on learning outcomes or convalescence) and their personal feelings about the willingness to live near forests and consent to change their use. In the second part, we asked about students' valuations, preferences, motivation and engagement in the usage and design of urban forests. For each question, several possible answers were proposed, as well as leaving room for other suggestions.

The normality of data was tested with the Kolmogorov-Smirnov test. Data were also tested for homogeneity of variance by using the Levene's test of equality of error variances and skewness. The use of a non-parametric test was dictated by the heavily skewed data distributions in the examined groups, and the fact that attempts to transform the data to that of normal distribution did not provide the expected results. The Kruskal-Wallis test was used to determine the differences among the four tested student groups. To identify differences among responses of the student groups, the multiple comparison test was done. The Mann-Whitney U test was used to test statistically significant differences in answering the ecological, economic and social category questions regarding gender. The level of significance for all statistical tests was accepted at $\alpha=0.05$. Analyses were carried out using STATISTICA 13.1 software.

\section{Results}

Regarding ecological questions, statistically significant differences in some answers were noted. Significant differences were noted when answering the question: "Do forest areas in the city improve air quality?". Biology students answered the question slightly differently. The lowest percentage of Biology students (87\%) answered positively on this question. This seems a very surprising result. The general percentage of students who answered this question positively was between $96 \%$ and $100 \%$.

Statistically significant differences were also noted when answering the following question: "Do forest areas in the city improve the hydrological situation of cities?". There were significant differences among the answers given by students of Economics, Psychology and students of Spatial economy and Biology. Students of Biology (78\%) and Spatial economy (68\%) more often answered this question positively. The lowest percentage of correct answers among Biology students is also surprising with regard to the question about 
the possible growth of forest areas on our planet. Between 59\% (Biology) to 84\% (Spatial economy and Psychology) of students answered correctly.

Most students (from 80\% - Economics to 94\% - Spatial economy, Psychology) indicated that forest areas in the city affect the increase in biodiversity. It is amazing that this percentage is not equal to or near the maximum. From 77\% (Economics) to 89\% (Psychology) of students said that urban areas in the city improve cities' climate. The percentage of students who indicated that forest areas in the city should be left to natural succession, in which we leave dead wood, was much lower (from $48 \%$ - Economics to $65 \%$ - Biology). The percentage of Biology students responding positively to this issue was the highest, although quite low. The assumption did not bear fruit that among naturalists, the percentage would be significantly higher than people who had other professional and intellectual interests. In general, statistically significant differences among groups of students were noted for questions classified as ecological (Kruskal-Wallis test, $\mathrm{H}=10.86613$, $\mathrm{p}<0.0125$ ).

Regarding questions on economic issues, statistically, significant differences were noted for the following question: "Do the city's forest areas add value to nearby properties?" Students of Spatial economy most often gave a positive answer to this question (86\%). From 51\% (Economics) to $62 \%$ (Psychology), students claim that the city's forest areas are used economically. A low number of students (from 12\% - Economics to 28\% - Biology) accepted the urban policy of reassigning forest areas in cities to fulfil other urban functions. There were no statistically important differences among the answers; however, it is telling that the highest percentage of students came from the discipline of Biology. The percentage of students declaring a readiness to pay more for the property due to its location in the vicinity of forest areas was relatively high and similar throughout all the examined groups (68-76\%). Taking the four economic questions together, there were no statistically significant differences among the examined groups of students (Kruskal-Wallis test, $\mathrm{H}=2.251050 \mathrm{p}<0.5220$ ).

Similarly, in the case of questions included in the social category, statistically significant differences were noted in the case of one of the four questions: "Can the location of forest areas in the vicinity of schools positively influence the learning outcomes of students of such a school?" Biology (74\%) and Psychology (80\%) students more often answered this question positively. The proportion of students declaring their willingness to live near the forest areas in the city was high and similar in all examined groups (85-96\%). The number of students claiming that the location of forest areas in the vicinity of a hospital may positively affect the recovery of patients was high and similar in all groups (84-92\%). The smallest number of Biology students answered this question in the affirmative. The percentage of students who 
believed that natural forest areas in urban areas should be transformed in order to increase their accessibility for residents was quite diversified in the studied groups. It was the lowest for Biology students (37\%) and the highest for Spatial economy students $(60 \%)$. In general, there were no statistically significant differences among the examined groups of students with regard to the social questions (Kruskal-Wallis test, $\mathrm{H}=5.85794 \mathrm{p}=0.1187$ ).

The differences in responses were also analysed, taking into account the gender of students. Statistically significant differences were noted only for questions from the ecological category. Female students of Economics were more likely to correctly answer ecological questions than male students of Economics (The Mann-Whitney U test, $U=393, \mathrm{p}<0.02744$ ).

Students were also asked four open questions concerning citizens' preferences, motivation and engagement in the usage and design of urban forests. In general, there were statistically significant differences in students' proposals concerning the directions of forest development in urban areas (Kruskal-Wallis test, $\mathrm{H}=131.0934, \mathrm{p}=0.000$ ). One-third of students proposed leaving urban forests in a natural state. The largest number of Biology students proposed this solution (43\%). Most students, irrespective of their faculties, proposed setting up walking and cycling paths in urban forests (usually over $80 \%$ ). Interestingly enough, only $68 \%$ students of Biology proposed such a solution. There were statistically significant differences regarding this proposal (Kruskal-Wallis test, $\mathrm{H}=10.35948, \mathrm{p}<0.0157$ ). A similar number of students of all faculties suggested the placement of topographic signs and maps, or the placement of benches in forests. Such solutions enjoyed the least recognition among Biology students.

Another question was to determine how often a person spends time in the forest areas of his/her city. The „several times a month" option was most often chosen by students of all faculties (Kruskal-Wallis test, $\mathrm{H}=164.3872$, $\mathrm{p}=0.000$ ). The option „several times a week” was most often indicated by Biology students, although it was only $5 \%$ of students. Students were asked to identify their motives for spending time in the forest areas of their city. Most often, students indicated the need for a walk (over $80 \%$ ), followed by contact with nature (about 60\%). There were no statistically significant differences for these proposals among the groups of students studied. Educational significance was the least frequently indicated. Biology students most often pointed to this proposal (32\%, Kruskal-Wallis test, $\mathrm{H}=43.61472$, $\mathrm{p}=0.000)$. Biology students most often pointed to the role of collecting forest gifts $(46 \%$, Kruskal-Wallis test, $\mathrm{H}=13.77951 \mathrm{p}<0.0032)$.

The last survey question concerned the type of actions that the respondent has taken so far for the benefit of trees and forests in their place of residence. Most often, students of all faculties pointed to a conversation with 
others, the purpose of which was to recognise the importance of forests in human life (between 50\% to 60\%). Planting trees was indicated by respondents as the second most frequently undertaken action (24\% to $43 \%$ ). Biology students most often chose both of these activities. Other activities (signing a protest, photography, participation in a happening, a new form of nature protection) were rarely undertaken by students of all faculties (Kruskal-Wallis test, $\mathrm{H}=507.4831, \mathrm{p}=0.000$ ).

\section{Discussion and conclusions}

Despite so many ecological, social and economic benefits, urban forests are not universally recognised and appreciated. The research has discovered that urban forests are underestimated resources. The study shows that the young generation of Poles does not fully recognise the multi-beneficial aspects of urban forests. This lack of awareness probably has a direct connection to the limited activities of these young people, both in terms of usage and in terms of their engagement in the development of these areas.

The respondents' knowledge below expectations concerning the important role of urban forests, especially among Biology students, proved to be most revealing. Their answers regarding preferences, motivation and engagement in the usage and design of urban forests pointed to rather low awareness of the role and importance of these areas. Nevertheless, we should not overlook the fact that there are high discrepancies in terms of accessibility to urban forests in the cities of the Silesian Voivodeship. Limited accessibility, in turn, affects both the manner in which these areas are used, as well as people's general perceptions of them.

Urban forestry presents multidisciplinary aspects of sustainable cities that should be widely incorporated into the stages of planning and management. We still lack a holistic understanding of the benefits delivered by urban forests. There is a clear need to share and promote knowledge about the efficacy of urban forests. An important aspect of this is to learn from the great potential embedded in experiences and studies that have so far been documented and to explore what specific actions may be required to enact progress. There is a need to share information among countries and disciplines to facilitate mutual learning and foster the development of urban forests. Understanding the complexity of urban and natural relationships requires approaches from both natural and social sciences. We need to examine the evidence of the local and global benefits of urban forests and communicate this information to local communities. As our study shows, there is a need to fill in the knowledge gap in this field. The research adds to the understanding 
of the complex meaning of forests in cities. It is beyond the scope of this paper to elaborate further on the detailed issues of urban forestry.

Originally focused on more natural and rural areas, a growing number of studies show the potential of ecosystem services for an urban world (Krasny et al., 2014; McPhearson et al., 2015). We observe an increasing recognition of the importance of urban green spaces for the quality of life in cities. In urban areas, the co-benefits of the availability of urban green spaces should include their multi-functionality. The environmental aspects should be linked to socio-economic factors, as well as to the general quality of life. Achieving this involves developing joint links with approaches from the domains of environmental, social and economic sciences. The concept of ecosystem services expresses that human and natural factors and processes are interlinked and impact each other.

In order to unlock the potential of urban forests, the development of the governance approach is a key challenge. Rapid urbanisation requires more active citizens who are aware of the ecological, social and economic difficulties. Adopting a mosaic of the governance approach in tandem with urban forestry delivers a diversity of benefits that produce better outcomes for cities. Combining the strategy of public participation and urban forestry is a direction that leads towards sustainable cities. Fostering stewardship activities that engage local citizens in designing and maintaining urban forests can be an important strategy for increasing awareness and engagement with these spaces. The governance model and inclusive methods of shaping urban forests increase the ecological and social resilience of cities.

Knowledge about the specific impact of urban forests on both the environment and residents is an essential part of general sustainable strategies for cities. What is more, the urban ecological footprint extends far beyond municipal boundaries. Urban areas play a pivotal role in global ecosystems. A significant consequence of urban development is habitat loss that results in widespread loss of biological diversity. While scientists have made great strides in determining principles and key factors fundamental to preserving biodiversity, their work will have little impact unless it is understood and implemented by those who are making on-the-ground decisions pertaining to land use.

Do residents want their cities to be greener and more natural? The positive answer to this question should be adopted within the practices of local governmental policy. 


\section{The contribution of the authors}

Agnieszka Sobol: conception - 50\%, literature review - 50\%, acquisition of data $50 \%$, analysis and interpretation of data $-50 \%$

Piotr Skubała: conception - 50\%, literature review - 50\%, acquisition of data $-50 \%$, analysis and interpretation of data $-50 \%$

\section{References}

Albert M., Marzluff J.M., 2004. Ecological resilience in urban ecosystems: Linking urban patterns to human and ecological functions. Urban Ecosystems 7, 241-265. DOI:10.1023/B:UEC0.0000044038.90173.c6.

Andersson E., McPhearson T., Kremer P., Gomez-Baggethun E., Haase D., Tuvendal M., Wurster D., 2015. Scale and context dependence of ecosystem service providing units Ecosystem Services 12, 157-164. https://doi.org/10.1016/j.ecoser.2014. 08.001 .

Balian E., Eggermont H., Le Roux X., 2014. Outputs of the Strategic Foresight workshop "Nature-Based Solutions in a BiodivERsA context", Brussels June 11-12 2014. BiodivERsA report, $45 \mathrm{pp}$.

Birch, E.L., Wachter, S.M., 2008. Growing Greener Cities: Urban Sustainability in the Twenty-First Century. University of Philadelphia Press, Philadelphia, PA, USA.

Bowler D.E., Buyung-Ali L., Knight T.M.,. Pullin A.S., 2010. Urban greening to cool towns and cities: a systematic review of the empirical evidence. Landscape and Urban Planning, 97(3), 147-155. http://dx.doi.org/10.1016/j.landurbplan.2010. 05.006.

Bragg R., Wood C., Barton J., Pretty J., 2013. Measuring Connection with Nature in Children Aged 8-12: A Robust Methodology for the RSPB. Essex Sustainability Institute and School of Biological Sciences, University of Essex.

Buijs A.E., Mattijssen T.J., Van der Jagt A.P., Ambrose-Oji B., Andersson E., Elands B.H., Møller M.S., 2017. Active citizenship for urban green infrastructure: fostering the diversity and dynamics of citizen contributions through mosaic governance. Current Opinion in Environmental Sustainability 22, 1-6. https://doi.org/10.1016/ j.cosust.2017.01.002.

Carrus G., Scopelliti M., Lafortezza R., Coangelo G., Ferrini F., Salbitano F., Agrimi M., Portoghesi L., Semenzato P., Sanesi G., 2015. Go greener, feel better? The positive effects of biodiversity on the well-being of individual visiting urban and periurban green areas. Landscape and Urban Planning 134, 221-228. http://dx.doi. org/10.1016/j.landurbplan.2014.10.022.

Chan K.M.A., Guerry A.D., Balvanera P., Klain S., Satterfield T., Basurto X., Bostrom A., Chuenpagdee R., Gould R., Halpern B.S., Hannahs N., Levine J., Norton B., Ruckelshaus M., Russell R., Tam J., Woodside U., 2012. Where are Cultural and Social in ecosystem services? A framework for constructive engagement. Bioscience 62(8), 744-756. https://doi.org/10.1525/bio.2012.62.8.7.

Danforda R.S., Strohbach M.W., Warren P.S., Ryand R.L., 2018. Active Greening or Rewilding the city: How does the intention behind small pockets of urban green affect use?. Urban Forestry and Urban Greening 29, 377-383. doi : 10.1016/j. ufug.2017.11.014 
Dooling S., 2009. Ecological gentrification: a research agenda exploring justice in the city. International Journal of Urban and Regional Research 33(3), 621-639. http://dx.doi.org/10.1111/ j.1468-2427.2009.00860.x.

European Commission, 2015. Towards an EU research and innovation policy agenda for nature-based solutions and re-naturing cities. Final Report of the Horizon 2020 expert group on "Nature-Based Solutions and Re-Naturing Cities", European Commission, Brussels, Belgium.

European Environment Agency, 2012. Climate change, impacts and vulnerability in Europe 2012. An indicator-based report. European Environmental Agency, Copenhagen, Denmark.

Germann-Chiari C., Seeland C., 2004. Are urban green spaces optimally distributed to act as places for social integration? Results of a geographical information system (GIS) approach for urban forestry research. Forest Policy and Economics 6, 3-13. doi: 10.1016/S1389-9341(02)00067-9.

Gill S.E., Handley J.F., Ennos A.R., Pauleit S., 2007. Adapting cities for climate change: the role of the green infrastructure. Built Environment 33, 115-133. http://dx. doi.org/10.2148/benv.33.1.115.

European Environment Agency, 2017. Air quality in Europe - report 2017, European Environment Agency, Luxembourg. Retrieved January 5th, 2021 from https:// www.eea.europa.eu/publications/air-quality-in-europe-2017.

European Union, European Environment Agency, CHM, United Nations Decade on Biodiversity, 2015. Mapping and Assessment of Ecosystems and Their Services (MAES). Retrieved January 5th, 2021 from http://biodiversity.europa.eu/maes.

Haase D., Larondelle N., Andersson E., Artmann M., Borgström S., Breuste J., GomezBaggethun E., Gren Å., Hamstead Z., Hansen R., Kabisch N., Kremer, P., Langemeyer J., Rall E.L., McPhearson T., Pauleit S., Qureshi S., Schwarz N., Voigt A., Wurster D., Elmqvist T., 2014. A quantitative review of urban ecosystem service assessments: concepts, models, and implementation. Ambio 43(4), 413-433. http://dx.doi.org/10.1007/s13280-014-0504-0.

Fischer L.K, Kowarik I, Botzat A., Honold J., Haase D., Kabisch N., 2016. Interaction of biological and cultural diversity of urban green spaces. GREEN SURGE Deliverable 2.2. Research report.

Haffner J., 2015. The dangers of eco-gentrification: what's the best way to make a city greener? The Guardian, May 6th. Retrieved January 5th, 2021 from http://www. theguardian.com/cities/2015/may/06/dangers-ecogentrification-best-way-ma ke-city-greener.

Hartig T., Mitchell R., de Vries S., Frumkin H., 2014. Nature and health. Annual Review of Public Health 35, 207-228. http://dx.doi.org/10.1146/annurev-publhealth032013-182443.

Irvine K.N., Warber S.L., Devine-Wright P., Gaston K.J., 2013. Understanding urban green space as a health resource: a qualitative comparison of visit motivation and derived effects among park users in Sheffield, UK. International Journal of Environmental Research and Public Health 10(1), 417-442. http://dx.doi.org/10.3390 /ijerph10010417.

Jansson M., Lindgren T., 2012. A review of the concept management in relation to urban landscapes and green spaces: toward a holistic understanding. Urban Forestry \& Urban Greening 11, 139-145. doi: 10.1016/j.ufug.2012.01.004.

Kabisch N., Frantzeskaki N., Pauleit S., Naumann S., Davis M., Artmann M., Haase D., Knapp S., Korn H., Stadler J., Zaunberger K., Bonn A., 2016. Nature-based solu- 
tions to climate change mitigation and adaptation in urban areas: perspectives on indicators, knowledge gaps, barriers, and opportunities for action. Ecology and Society 21(2), 39. http://dx.doi.org/10.5751/ES-08373-210239.

Keniger L.E., Gaston K.J., Irvine K.N., Fuller R.A., 2013. What are the benefits of interacting with nature? International Journal of Environmental Research and Public Health 10(3), 913-935. http://dx.doi.org/10.3390/ijerph10030913.

Kowarik I., Körner S. (Eds.), 2005. Wild Urban Woodlands. New Perspectives for Urban Forestry. Springer-Verlag, Berlin, Heidelberg.

Kowarik I., 2011. Novel urban ecosystems, biodiversity, and conservation. Environmental Pollution 159, 1974-1983. http://dx.doi.org/10.1016/j.envpol.2011.02. 022.

Krasny M.E., Russ A., Tidball K.G., Elmqvist T., 2014. Civic ecology practices: participatory approaches to generating and measuring ecosystem services in cities. Ecosystem Services 7, 177-186. https://doi.org/10.1016/j.ecoser.2013.11.002.

Lawrence A., De Vreese R., Johnston M., Konijnendijk van den Bosch C. C., Sanesie G., 2013. Urban forest governance: Towards a framework for comparing approaches. Urban Forestry \& Urban Greening, 12(4), 464-473. https://doi.org/10.1016/ j.ufug.2013.05.002.

Lee A.C.K., Maheswaran R., 2011. The health benefits of urban green spaces: a review of the evidence. Journal of Public Health 33, 212-222. https://doi.org/10.1093/ pubmed/fdq068.

Littke H., 2015. Planning the green walkable city: conceptualising values and conflicts for urban green space strategies in Stockholm. Sustainability 7(8), 11306-11320. doi: 10.3390/su70811306.

Luederitz C., Brink E., Gralla F., Hermelingmeier V., Meyer M., Niven L., Panzer L., Partelow S., Rau A.L., Sasaki R., Abson D.J., Lang D.J., Wamsler C., Von Wehrden H., 2015. A review of urban ecosystem services. Six key challenges for future research. Ecosystem Services 14, 98-112. https://doi.org/10.1016/j.ecoser.2015. 05.001 .

Lyytimäki J., Sipilä M., 2009. Hopping on one leg - the challenge of ecosystem disservices for urban green management. Urban Forestry \& Urban Greening 8(4), 309315. http://dx.doi.org/10.1016/j.ufug.2009.09.003.

McPhearson T., Andersson E., Elmqvist T., Frantzeskaki N., 2015. Resilience of and through urban ecosystem services. Ecosystem Services 12, 152-156. doi: 10. 1016/j.ecoser.2014.07.012.

Millennium Ecosystem Assessment (MA), 2005. Ecosystems and Human Wellbeing: Synthesis. Island Press, Washington DC.

Nowak D.J., Hirabayashi S., Ellis E., Greenfield E.J., 2014. Tree and forest effects on air quality and human health in the United States. Environmental Pollution 193, 119-129. https://doi.org/10.1016/j.envpol.2014.05.028.

Nowak D.J., Hirabayashi S., Doyle M., McGovern M., Pasher J., 2018. Air pollution removal by urban forests in Canada and its effect on air quality and human health, Urban Forestry \& Urban Greening 29, 40-48. http://dx.doi.org/10.1016/j.ufug. 2017.10.019.

Nowak D.J., Crane D.E., 2002. Carbon storage and sequestration by urban trees in the USA. Environmental Pollution 116, 381-389. https://doi.org/10.1016/S02697491(01)00214-7. 
Ostoic S.K., Konijnendijk Van den Bosch C.C., 2015. Exploring global scientific discourses on urban forestry. Urban Forestry \& Urban Greening 14, 129-138. doi: 10.1016/j.ufug.2015.01.001.

Peters K., Elands B., Buijs A., 2010. Social interactions in urban parks: stimulating social cohesion? Urban Forestry \& Urban Greening 9(2), 93-100. https://doi. org/10.1016/j.ufug.2009.11.003.

Raymond R.M., Brown G., Weber D., 2010. The measurement of place attachment: personal, community, and environmental connections. Journal of Environmental Psychology 30, 422-434. https://doi.org/10.1016/j.jenvp.2010.08.002.

Rupprecht C.D.D., Byrne, J.A., 2014. Informal urban greenspace: A typology and trilingual systematic review of its role for urban residents and trends in the literature. Urban Forestry \& Urban Greening 13, 597-611. http://dx.doi.org/10.1016/ j.ufug.2014.09.002.

Seto K.C., Fragkias M., Güneralp B., Reilly M.K., 2011, A Meta-Analysis of Global Urban Land Expansion, PlosOne 6 (8) : e23777. https://doi.org/10.1371/journal. pone.0023777.Song X.P., Tan P.Y., Edwards P., Richards D., 2018. The economic benefits and costs of trees in urban forest stewardship: A systematic review. Urban Forestry \& Urban Greening 29, 162-70. https://doi.org/10.1016/j.ufug. 2017.11.017.

The Environmental Protection Act of April 27th 2001 (Journal of Laws 2001 no. 62 item 627, as amended).

The Act on Spatial Planning and Management of March 27th 2003 (Journal of Laws 2003 no. 80 item 717, as amended).

The Act on the Protection of Nature of April 16th 2004 (Journal of Laws 2004 no. 92 item 880, as amended).

The Act on municipal local government of March 8th 1990 (Journal of Laws 1190 no. 16 item 95, as amended).

Turnhout E., Waterton C., Neves K., Buizer M., 2013. Rethinking biodiversity; From goods and services to "living with". Conservation Letters 6(3), 154-161. https:// doi.org/10.1111/j.1755-263X.2012.00307.x.

Vogt J.M., Hauer R.J., Fischer B.C., 2015. The costs of maintaining and not maintaining the urban forest: a review of the urban forestry and arboriculture literature. Aboriculture Urban Forest 41, 293-323.

Von Döhren P., Haase D., 2015. Ecosystem disservices research: a review of the state of the art with a focus on cities. Ecological Indicators 52, 490-497. http://dx.doi. org/10.1016/j.ecolind.2014.12.027.

Wolch J.R., Byrne J., Newell J.P., 2014. Urban green space, public health, and environmental justice: the challenge of making cities 'just green enough.' Landscape and Urban Planning 125, 234-244. http://dx.doi.org/10.1016/j.landurbplan.2014. 01.017.

Zhang J.W., Piff P.K., Iyer R., Koleva S., Keltner D., 2014. An occasion for unselfing: Beautiful nature leads to prosociality. Journal of Environmental Psychology 37, 61-72. http://dx.doi.org/10.1016/j.jenvp.2013.11.008. 